\title{
Analysis on Characteristics of Provenance of bauxite in Guizhou, China
}

\author{
Tao Cui \\ College of Resources and Environmental Engineering, Guizhou Institute of Technology, Guiyang, \\ 550003, China \\ cuitao1203@163.com
}

Keywords: Bauxite, Provenance, Guizhou.

\begin{abstract}
On the basis of previous studies, characteristics of provenance of bauxite in Guizhou were comprehensive analyzed, and draws the following conclusions: 1) All he Cambrian, Ordovician, Silurian, Devonian and Carboniferous have provided ore-forming materials for the formation of bauxite, but for different metallogenic regions, the main provenances are not the same; 2) Different parent rocks can provide ore-forming materials for bauxite formation in different stages, the same mother rock can also provide ore-forming materials for the same bauxite in different stages; 3) The sea level changes of South China Sea and Yangtze Sea have controled the formation of bauxite in Guizhou.
\end{abstract}

\section{Introduction}

Bauxite is an important strategic resource, which is not only the main material of aluminum refining, but also its associated rare earth elements have great economic value. Conducting research on the causes of bauxite is helpful for the bauxite exploration, and provenance is an important part for the research on the genesis of bauxite. Guizhou is rich in bauxite resources, in accordance with the former researchers' studies on provenances, mineralization age, petrologic and mineralogical characteristics, geochemical characteristics, mineralization process and mineralization model etc[1-6], bauxite in Guizhou can be divided into four metallogenic regions: WZD bauxite of northern Guizhou, Zunyi - Xifeng bauxite of northern Guizhou, Central bauxite, Southeastern bauxite (Fig. 1), the paper has comprehensively studied bauxite provenance features of the 4 metallogenic regions on the basis of previous researchers' works. There are differences and relations on the causes of the 4 metallogenic regions, while most of the previous studies only conducted individual analysis on each of the metallogenic regions. Research shows that despite the four metallogenic regions have differences in position, but they both have connections and differences in the provenances of ore forming; starting from the evolution of bauxite ore forming, this paper has analyzed each of the metallogenic regions and at the mean time conducted a comprehensive study of the four metallogenic regions as a whole, and summarized characteristics of provenance, to provide basic information and technical guidance for the exploration and development of bauxite.

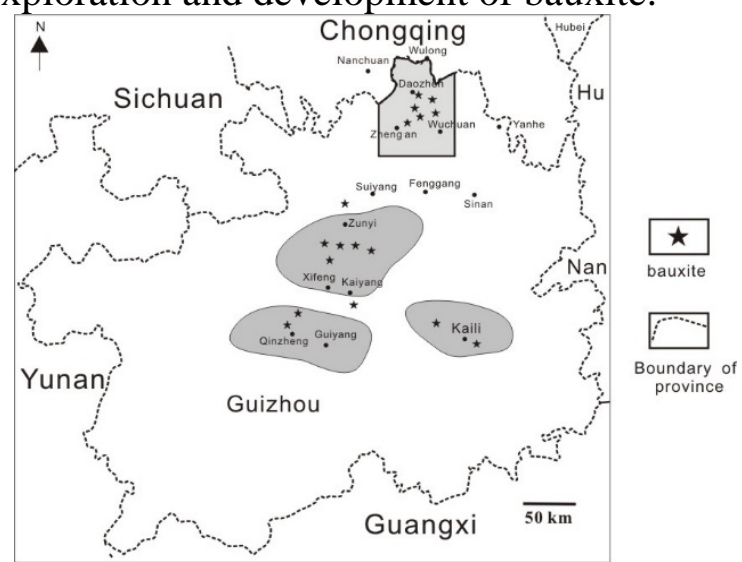

Fig. 1 Map showing the distribution characteristics of bauxite in Guizhou 


\section{Characteristics of Provenance of Bauxite}

When it comes to provenance, people always like to limit the provenance to the centralized formation at one or a certain period of time, this idea is not a problem for most of the minerals, but bauxite is different from conventional minerals, which belongs to a kind of weathering type mineral, the source is far more complex than general type of mineral. In the discussion of bauxite provenance, the following problems should be noted: First, the content of $\mathrm{Al}$ in the earth's crust is high, it is not a trace or rare element, any rock can become the source of bauxite, although the potential of different types of rock for formation of bauxite is not the same, but in theory, as long as the conditions are right, any form of rock can provide high-quality bauxite source [7-8], so in the analysis of bauxite provenance, the influence of subjective consciousness in "high quality provenance" should be excluded, in addition to the high aluminum content rock, the low aluminum content rock is also known as the main or sole source of bauxite, which provides a large number of mineral bauxite, forms high-quality bauxite deposits. Second, the bauxite mineralization process is very long, the formation of bauxite may experience the iterative process of deposition, exposure and erosion, in this process, more than one kind of rock and the same period exposure rock may provide the material source for the bauxite. The ore-forming parent material for bauxite formation may not only be provided by many kinds of rocks, at the mean time the variety of rock may have "time difference", "time difference" contains two meanings, one is the rock era is not the same, another is different rocks are exposed to weathering and denudation in a different era, these different times of rock in the bauxite formation had provided ore-forming materials in different times. Third, not only different rocks can provide ore-forming materials for a bauxite deposit formation in different times, but also for the same rock, it can provide minerals for the same bauxite in different times, besides, bauxite deposits of different times may have the same provenance.

\section{Characteristics of Provenance of Bauxite in Guizhou}

\subsection{Basic characteristics of provenance for the four major bauxite metallogenic regions of Guizhou}

Many experts and scholars have studied the provenance of bauxite in Guizhou, among which the researches on WZD bauxite are more detailed, while the studies on mining regions of Zunyi-Kaiyang bauxite, Qingzhen-Xiuwen and Wongan-Fuquan-Kaili-Huangping are relatively weak. Controversies on the provenances of WZD bauxite are few, basically believe that provenances are mainly provided by the Han Jia Dian formation shale and Huanglong Formation limestone (Yu et al., 2014; Gu et al., 2013), besides a small amount of basalt and other sources. In addition to WZD bauxite, the remaining three bauxite metallogenic regions are still lack of systematic research.

\subsection{Multi-source and multi period of provenance of bauxite in Guizhou.}

It seems that Guizhou's four largest bauxite metallogenic regions have big differences; in fact, they have a close relationship on the causes of formation. The strata that have direct contacts with the ore bearing rock series are Cambrian, Ordovician, Silurian, Devonian, Carboniferous, while for the four metallogenic regions, except the Central bauxite has thin Carboniferous strata in top, all the remaining regions are Permian. The comprehensive study in the region's paleogeographic characteristics shows that bauxite ore-forming process began in the Middle Ordovician exposed surface, in this process, with the sea level changes, different regions formed different floors, but eventually formed bauxite deposits were between the Carboniferous - Permian. In the process of mineralization, Cambrian, Ordovician, Silurian, Devonian, Carboniferous all have provided the provenances for bauxite formation, but the main provenances are not the same for different metallogenic regions. The provenances for WZD bauxite and Zunyi - Kaiyang bauxite are Cambrian, Ordovician, Silurian, Carboniferous, among which in addition to the Carboniferous strata is thin, and the rest all have provided a large amount of ore-forming materials for bauxite formation. The provenances of Qingzhen - Xiuwen bauxite region are mainly Cambrian, Ordovician and 
Carboniferous. The provenances of Wongan-Fuquan-Kaili-Huangping bauxite region are Cambrian, Ordovician and Devonian, and may clip a small amount of the Carboniferous. Both the Cambrian and Ordovician have provided provenances for Guizhou bauxite, but may have greater contribution for the formation of bauxite in northern Guizhou and central Guizhou, Silurian and Carboniferous are the main provenances for $\mathrm{Wu}$, Zheng and Dao bauxite region. The provenance of the Devonian is of great significance to the bauxite formation of southeastern Guizhou. The Carboniferous provenance has contributed to all the bauxite metallogenic regions, but excluding the northern Guizhou region, in which the proportion may not be too large. In addition to the above provenances, more ancient strata may also have contribution on the bauxite formation, but its proportion of bauxite provenances is relatively small.

The final formation of bauxite is usually a long process, the multiple sources of Guizhou bauxite means each metallogenic region consists of at least two parent rocks as the provenances. And the multi periods means that different mother rocks are not just provide provenance for bauxite at the same time, but divided into several stages. In addition to the Cambrian, Ordovician, Silurian, Devonian, Carboniferous, there are magmatic or metamorphic provenances contained near all the metallogenic regions.

\subsection{The unity of provenance of bauxite in Guizhou}

All the four Guizhou bauxite metallogenic regions have differences in provenances, ore-forming age, under the underlying strata, ore-forming process and deposit types, seemingly unrelated. But in fact, the formations of the 4 bauxite metallogenic regions are controlled by the South China Sea and Yangtze Sea, especially the sea level changes of the South China Sea. With the decrease of the sea level, the exposed surface of the metallogenic regions can be divided into three cases: 1) The large areas of the ore forming area and the surrounding area were exposed and eroded, to provide provenances for the formation of the bauxite; 2) Part of the metallogenic region was exposed and part of the region was flooded; 3) The large area of the metallogenic region is flooded, without exposed area or only few part of the region was exposed. Early large area exposed lead to erosion of the Cambrian, Ordovician strata and provided provenances for the formations of the four bauxite metallogenic regions; with the sea level changes, the metallogenic regions had repeated alternately into exposed and submerged, there was a bauxite mineralization when exposed, and transgression would take away the impurities generated from the mineralization process, while continuing to receive deposits; in this process multiple ore source layers had provided ore-forming materials for bauxite formation in multi periods. Overall, the formations of the four metallogenic regions have unity characteristics, and were subject to be controlled by the sea level changes in the South China Sea and Yangtze Sea, changes in the South China Sea determined the formations of Zunyi - Xifeng bauxite of northern Guizhou, Central Guizhou bauxite, Southeastern of Guizhou bauxite, while the Yangtze Sea level changes determined the formation of WZD bauxite of northern Guizhou.

\section{Conclusions}

Cambrian, Ordovician, Silurian, Devonian, Carboniferous are sources of bauxite in Guizhou, but for different metallogenic regions, the main provenances are not the same, the Precambrian strata may also contribute to the bauxite formation, but the proportion in the bauxite provenances is relatively small. Different mother rocks do not provide provenances for bauxite at the same time, but are divided into several stages, the same mother rock can also provide provenances for the bauxite in different stages. The formations of the 4 bauxite metallogenic regions have unity features, which are controlled by the sea level changes in the South China Sea and the Yangtze Sea, and the sea level changes in the South China Sea and the Yangtze Sea have directly controlled the formation and supply of ore forming materials of all the metallogenic regions.

\section{Acknowledgement}

This work was supported by the provincial project of characteristics of REE and its transferring disciplinarian in mineralizing process of the bauxite in northern Guizhou, China (No.LH [2014]7358), 
the project of analysis on geochemical behaviors of Platinum group elements in Emeishan basalt (No.XJGC20131204), Guizhou Institute of Technology and the Guizhou Collaborative Innovation Center of Strategic Minerals Resource Development, Guizhou Institute of Technology, Guiyang, 550003, China.

\section{References}

[1]. Du YS, Zhou Q, Jin ZG, Lin WL, Wang XM, Yu WC. Mineralization model for the early permian bauxite deposits in Wuchuan-Zheng,an-Daozhen area, northern Guizhou Province. Juornal of palaeogeography, Vol.16(2014) No.1,p.1-8.

[2]. Du YS, Zhou Q, Jin ZG, Lin WL, Zhang XH. Adcances in basic geology and metallogenic regularity study of bauxite in Wuchuan-Zheng,an-Daozhen area, northern Guizhou, China. Geological science and technonlogy information, Vol.32(2013) No.1,p.1-6.

[3]. Wang DH, Li PG, Qu WJ, Yin LJ, Zhao Z, Lei ZY, Weng SF. Discovery and preliminary study of the high tungsten and lithium contens in the Dazhuyuan bauxite deposit, Guihou, China. Science China: Earth Science. Vol.56(2013) p.145-152.

[4]. Wang Xiaomei, Jiao Yangquan, Du Yuanshen. Rare earth element geochemistry of bauxite in Wuchuan -Zheng,an -Daozhen area, northern Guizhou, province. Geological science and technonlogy information. Vol.32(2013) p.27-33.

[5]. Gu J, Huang ZL, Fan HP, Ye Lin, Jin ZG. Provenance of lateritic bauxite deposits in the Wuchuan-Zheng,an-Daozhen area, northern Guizhou province, China: LA-ICP-MS and sims $\mathrm{U}-\mathrm{Pb}$ dating of detrial zircons. Journal of Asian earth sciences.

[6]. Wu GH, Zhang BS, Guo CL, Wang CL, Gao H. Detrital zircon U-Pb dating for the Silurian in northern tarin basin and its significance. Geotecton et Metallogenia. Vol.33(2009) p.418-426.

[7]. Bárdossy G. Karst bauxites, bauxite deposits on carbonate rocks. London, Developments in Economic Geology.Vol.14(1990) p.320-332.

[8]. Bushinsky. Bauxite geology. Beijing: Geology Press. 1984,p.129-130. 